Lógica dos

paradoxos:

$$
\begin{aligned}
& \text { Oadánér } \\
& \text { Jivo }
\end{aligned}
$$




\title{
ELENA VÁSSINA
}

\author{
ELENA VÁSSINA \\ é professora de Letras \\ Russas do Departamento \\ de Letras Orientais da \\ FFLCH-USP.
}

s primeiras experiências de Tolstói (1828-

1910) em gênero dramático-ONiilista

e A Família Contaminada - da-

tam de 1862. O conde esboçou essas peças para apresentações caseiras (em muitas famílias da nobreza russa, existia uma longa tradição de espetáculos amadores) e nunca as levou a sério. Por isso é comum se afirmar que o verdadeiro Tolstói dramaturgo se forma bastante tarde, depois de ter sido consagrado como o autor dos magníficos romances $G u e r$ ra e Paz (1863-69) e Anna Karenina (1878) e depois de ter passado pela profunda crise espiritual retratada em sua Confissão (1879). Ele escreve a sua primeira obra dramática séria, uma verdadeira tragédia popular, O Poder das Trevas, em 1886. Concebida pelo próprio autor como uma "peça para o povo", ela logo consagra Tolstói entre os clássicos da criação dramática na Rússia e no exterior (já em 1887, o diretor francês

A. Antoine encenou $O$ Poder das Trevas em seu Teatro Livre, em Paris). E a peça seguinte, Os Frutos da Civilização, só prova o incontestável talento de Tolstói-dramaturgo. Mas talvez o seu último drama, O Cadáver Vivo, possa servir como o mais impressionante exemplo da liberdade e magnitude do gênio literário-dramático tolstoiano.

O reconhecido teórico da literatura Mikhail Bakhtin, no ensaio “Tolstói Dramaturgo" (1929), analisa como e por que o escritor chegou à forma dramática e acha que isso aconteceu devido "à crise da palavra épica e autoral", que Tolstói percebera, com clareza, no início dos anos 80, após o que lhe 
foram "abertas novas e essenciais possibilidades, contidas na forma dramática"1. De uma maneira paradoxal, a arte teatral, tão desprezada por Tolstói por se tratar da "arte falsa", "cheia de convenção", de repente ganhou do escritor peças importantíssimas. Mas parece-nos importante observar também que essa adesão tardia de escritor maduro ao gênero teatral é muito característica para toda a literatura russa, clássica e contemporânea. Por exemplo, A. Púchkin, M. Liérmontov, N. Gógol, A. Tchékhov, entre outros, aderem ao drama já na segunda metade de seus percursos artísticos, e a linguagem dramática tornase para eles o meio importante da comunicação viva e do diálogo eficiente com seus leitores e espectadores que, no ato de assistir ao espetáculo teatral, unem-se, segundo a feliz definição de Lotman, “em uma personalidade coletiva" . Com efeito, a especificidade de comunicação dramática reforça as aspirações de vocação profética, fundamental para a literatura russa, em geral, e, em particular, tão marcante para Tolstói. No seu ensaio sobre Shakespeare, Tolstói afirma que "somente pode escrever o drama aquele que tem o que falar a homens, dizer-lhes algo importante sobre a relação do ser humano com Deus, com o mundo, com tudo o que é eterno e infinito"3.

A idéia de obra muito similar ao drama O Cadáver Vivo data dos meados da década 1890. Em 9 de fevereiro de 1884, Tolstói anota no seu diário que teve uma idéia clara de novela que representasse dois homens. Primeiro seria um ser libertino, perdido, decaído até se desprezar e ser desprezado, mas levado a tal situação só por causa da sua própria bondade. O outro, ao contrário, teria aparência de pureza, seria honrado e respeitado, "um aristocrata ideal", porém cheio de frieza e privado de amor ${ }^{4}$. O enredo do drama $O$ Cadáver Vivo, porém, começa a se concretizar somente no final dos anos 90, a partir de circunstâncias reais, referentes a um processo que envolvia o casal Grímer, que Tolstói conhecia pessoalmente. Ekaterina Grímer, que não suportava mais a vida com um marido decaído e alcoólatra, resolveu realizar a simulação de sua mor- te para que, obtendo o divórcio, pudesse se casar novamente com o homem que amava. Assim, o marido lhe teria escrito uma carta na qual the comunicava que, desesperado quanto à falta de possibilidade de consertar sua vida, decidia suicidar-se. Ekaterina Grímer entregou a carta do marido à polícia e logo a roupa de Nikolái Grímer foi encontrada, boiando no Rio Moskvá, coberta de gelo, assim como seus documentos de identificação. Pouco depois, foi retirado, de dentro do rio, o cadáver de um desconhecido, que foi tomado como o do falecido marido. Ekaterina Grímer casou-se pela segunda vez. No entanto, não tardou a esclarecer-se que seu primeiro marido estava, de fato, vivo: os dois cônjuges foram entregues à justiça e condenados ao exílio na Sibéria.

Partindo dessa história real, Tolstói começa escrever o seu drama no final de 1897. Em 29 de dezembro, ele anotou no seu diário: "Ontem, o dia todo, estava se construindo o drama-comédia $O$ Cadáver". No ano seguinte, o escritor continua pensando "como seria bom escrever uma obra em que fosse claramente refletida a fluidez do ser humano, o fato de que ele próprio ora é malvado, ora é anjo, ora é sábio, ora é idiota, ora é forte, ora é um ser fraquíssimo" 5 . (A idéia da fluidez do caráter humano destaca-se como uma das principais no método artístico e nas reflexões filosóficas de Tolstói. Ela se reflete tanto na criação dos personagens, quanto na minuciosa análise de si mesmo, feita nos seus diários escritos durante toda a vida, a partir de 18 anos. O escritor acha que "um dos maiores erros em apreciação de pessoa é que o chamamos, definimos de inteligente, tolo, bom, mau, forte, fraco, enquanto ser humano é tudo, e uma substância fluida".)

Mas o verdadeiro trabalho com a peça foi iniciado somente em janeiro de 1900 depois que Tolstói assistiu a Tio Vânia, de Tchékhov, que tinha estreado havia dois meses, no palco do Teatro de Arte de Moscou. O resultado dessa visita do escritor ao Teatro de Arte de Moscou era inesperado, do ponto de vista de consequiências artísticas. Tolstói, segundo as próprias anotações no 
diário, ficou tão indignado com Tio Vânia que decidiu retomar a idéia do "drama-comédia" O Cadáver e logo fez o esboço. A raiva impulsionou Tolstói a escrever a peça, cujo nome seria definido, posteriormente, na sua versão final, com oxymoron, ou seja, com uma junção impossível de palavras: $O$ Cadáver Vivo ${ }^{7}$. Mas de um jeito muito paradoxal (e, também, muito tolstoiano) o drama criado por polêmica artística com Tchékhov viria a ser o drama mais tchekhoviano em toda a obra de Tolstói. Escrita por um autor “indignado" com Tio Vânia, a última peça de Tolstói está bem próxima dos dramas de Tchékhov, mais se assemelhando a eles do que se diferenciando.

Em outubro de 1900, a notícia da nova peça de Tolstói, O Cadáver Vivo, alcançou a imprensa e, logo, Nemiróvitch-Dântchenko visitou Tolstói na sua propriedade rural, Iásnaia Poliana, com o propósito de obter a peça para encenação. No entanto, a família Grímer receava que esse espetáculo pudesse atrair uma nova onda de sensacionalismo em torno do processo escandaloso que inspirou a peça e pediu a Tolstói que não liberasse o texto para o teatro. $\mathrm{O}$ escritor prometeu atender ao pedido dos Grímer. Alegando que a peça ainda não estava terminada, Tolstói, naquele momento, recusou o pedido de Nemiróvitch-Dântchenko, mas prometeu que permitiria a montagem do drama no palco... só após a sua morte.

O Teatro de Arte de Moscou foi o primeiro grupo a obter o direito de encenar a peça, logo após a morte de Tolstói, em 1910. Stanislávski e Nemiróvitch-Dântchenko trabalharam em conjunto para montar $O$ Cadáver Vivo, que veio a ser "um dos espetáculos mais maravilhosos daquele teatro" . O sucesso da estréia no Teatro de Arte de Moscou era profético: ele se tornou oprenúncio do destino, incrivelmente bemsucedido, de $O$ Cadáver Vivo no teatro do século XX . O drama de Tolstói foi mais do que oportuno, revelando tudo o que havia de "tolstoiano" na natureza artística do teatro: verdadeira manifestação de amor pelo ser humano - mesmo que, às vezes, seja apresentado como pecador -, bem como a expressão de uma fé profunda de que, em cada ser humano, existe, afinal, algo de "divino". E não há como não concordar com o respeitado historiador da literatura russa D. Sviatopolk-Mírski, que afirmou que, dessa última peça de Tolstói, transbordam

"[...] uma enorme piedade, cheia de ternura, para com toda a humanidade, perdida e pecadora, e um respeito ao sofrimento humano, quer se trate de um alcoólatra, abandonado por todos, ou de uma soberba mãe, da alta-sociedade. $O$ Cadáver Vivo representa a última manifestação do gênio tolstoiano. Está evidente que a peça foi escrita por uma pessoa muito idosa, com aquela amplitude e suavidade do olhar que, quando acontecem de surgir, são o melhor enfeite da velhice"'

O próprio Tolstói reconheceu que, em $O$ Cadáver Vivo, ele "não se propunha estabelecer quaisquer metas didáticas ou educacionais, submetendo-se, unicamente, à emoção artística" ${ }^{10}$. A peça consegue ultrapassar a inclinação melodramática e, sendo isenta de artificialismo teatral, aproxima-se da linguagem do novo drama. Isso proporciona uma oportunidade surpreendente de vivenciar toda a profundeza e a sutileza dos sofrimentos psicológicos, não apenas por meio das palavras, mas por tudo aquilo que está oculto, atrás do verbal. É preciso observar que Tolstói, como nenhum outro clássico russo, sabia de maneira simplesmente genial descrever, com vastíssima diversidade de nuances, a dificílima “dialética da alma humana". Toda a estrutura do drama está construída sobre aquilo que deixou de ser dito, em cima das insinuações, da contradição, indefinida, das reações emocionais dos personagens. Já em um dos primeiros ecos à publicação (póstuma) de $O$ Cadáver Vivo, Serguéi Volkónski bem define as particularidades do método dramático de Tolstói: "E eis o que é surpreendente nesta peça [...] é que até nem as próprias palavras são importantes, nem são o principal; o que importa não é o que os personagens dizem, nem aquilo que eles fazem - eles não fazem nada - mas o que acontece com eles" 11 .
7 Com efeito, o nome da peça faz lembrar também a clássica obra de Gógol Almas Mortas.

8 Nemiróvitch-Dântchenko, Tvórt cheskoie nasliédie IHeranca Artística), Moscou, Ed. TAM 2003, p. 456

9 Sviatopolk-Mírski, Istória rússkoi literatúri IHistória da literatura Russa), Novossibirsk, Ed. Svinin sinoviá, 2005 , pp. 535-6.

10 Apud E. Poliakova, Teatr Lvá Tolstogo (Teatro de Liev Tolstói), Moscou, Ed. Iskússtvo, 1978, p. 241

11 Apud A. Anikst, Teoria drami v Róssii ot Púchkina do Tchékhova ITeoria do Drama na Rússia de Puchkin atéTchekhovl Moscou, Nauka, 1972, p. 540. 
Tal como os dramas de Tchékhov, Tolstói cria a tessitura do novo drama por meio de nuances e indefinições. Torna-se difícil determinar o conflito dramático em O Cadáver Vivo; os atos dos personagens, que eram considerados por Hegel uma das principais características do gênero dramático, perdem sua definição. Sendo assim, o drama de Tolstói elimina as oposições básicas entre protagonista e antagonista. Será que existe aqui a tensão irresolúvel do triângulo amoroso, típico do melodrama? À primeira vista, pode parecer que sim: Liza está infeliz com Fiédia Protássov, seu esposo sempre bêbado, gastador e decaído, e se apaixona por Víctor Kariénin, um homem impecável de todos pontos de vista. (Certamente, na criação desse personagem, observa-se a relação paródica do escritor com sua própria obra anterior. Kariénin do drama tem muito em comum, ou seja, é um "duplo" do seu homônimo do romance Anna Karenina.) Mas Tolstói nunca seria o grande artista de sutilezas da dialética da alma humana se se deixasse cair em banalidades melodramáticas. Vê-se como é complexo o relacionamento entre Liza e Fiédia; afinal, o que existe entre ambos é um amor, cheio de tortura, por não poderem viver juntos e, ao mesmo tempo, sofrerem em virtude disso. Para não atrapalhar "o futuro feliz" de Liza com Kariénin, Fiédia imita o suicídio, mas quando se verifica que ele ficou vivo e esse fato ameaça a nova vida conjugal da sua ex-mulher, Fiédia suicida-se de verdade.

E, muito embora Liza tentasse se convencer de que a vida "correta" com Kariénin lhe proporcionaria a felicidade, sentimos nas cenas de "felicidade conjugal" 12 de Liza e Kariénin toda a impossibilidade desse tipo de happy end. Por meio do seu predileto procedimento de estranhamento (ostraniênie), primeiro anotado por Víktor Chklóvski em seu clássico ensaio "A Arte como Procedimento"13, Tolstói mostra as convenções teatrais e a artificialidade da "felicidade conjugal" de Liza e Kariénin. O que é considerado "correto", pelo senso comum, torna-se tão enfadonho e careta que mata o sentimento vivo e verdadeiro que é o amor. A cena da felicidade de Liza e Kariénin não convence, é uma ficção, como “casa de bonecas" que se desmontaria assim que chegasse a carta de Fiédia, em que ele escreve: "Incomodo-os, portanto devo acabar comigo. [...] Devo acabar comigo. Então vou acabar comigo. Quando receberem essa carta, já não existirei" ${ }^{14}$. Assim que Liza lê essa frase, ela percebe que tudo é falso, que ela só finge que ama Kariénin.

A personagem principal de $O$ Cadáver Vivo é Fiódor Protássov, ou simplesmente Fiédia, como o chamam. Esse homem encantador, fraco e pecador, que costuma beber, ao ter abandonado a família e rompido com seu meio social (a mais alta sociedade russa, à qual pertencia também o conde Lev Tolstói), passa a vida em farras com os ciganos. A principal justificativa de Fiédia é de não poder levar uma vida "correta", que só tem a aparência de decente, mas que, em essência, está cheia das mentiras e hipocrisias dos condicionamentos sociais. Ele procura a verdade, a autenticidade e a naturalidade das relações humanas e da vida. E as encontra longe dos salões da alta sociedade, em meio aos ciganos, escutando as maravilhosas canções desse povo que, antes de tudo, valoriza a liberdade (na literatura russa, desde Púchkin, o tema do cigano sempre está ligado ao tema da liberdade). $\mathrm{E}$, mais uma vez, podemos anotar os traços autobiográficos da peça refletidos nesse motivo cigano, pois se sabe que Serguéi, o irmão mais velho de Lev, estava casado com a cigana Macha. Em O Cadáver Vivo é justamente a cigana Macha que encanta Fiédia. Fica óbvio que ele guarda uma paixão platônica por ela, por isso é tão difícil concordar com a sugerida idéia do divórcio, que a família de Kariénin exige dele, pois, para obtê-lo, Fiédia seria obrigado a mentir, confessando publicamente haver praticado adultério com a cigana. Quando o príncipe Abriézkov, a pedido da família Kariénin, vem falar com Fiédia sobre o divórcio, Fiédia lhe responde:

"Que devo fazer? Ponha-se no meu lugar. Nem tento me tornar melhor. Sou um canalha. Mas há coisas que não posso fazer 
ele cria o retrato de Fiédia: antes de surgir no palco, ele é, ao mesmo tempo, "ruim" e "maravilhoso", "trapo" e "encantador". A lógica do paradoxo também se torna a base do enredo: Fiédia é considerado "o cadáver vivo" porque fingiu que se suicidara. Mas, ao mesmo tempo, é óbvio que, para o autor, Fiédia é o herói mais vivo, que está vivendo de verdade e não fingindo viver, como fazem muitas outras personagens da peça. A situação dramática da peça é tão paradoxal que parece uma comédia absurda: o homem é julgado porque ficou vivo e não se suicidou.

O Cadáver Vivo trata do drama do "homem natural", que não segue os princípios estabelecidos e aceitos por todos. Sobre a personagem principal, Fiédia Protássov, "pesa a maldição da riqueza original"16, aquela mesma que o próprio Tolstói passou a sentir tão fortemente no final da sua vida. Essa "maldição da riqueza" e o motivo da vida indevida também definem outro tema muito importante para a obra do último período de Tolstói - o da retirada, da partida ou fuga, sendo este um tema profundamente autobiográfico, segundo a anotação precisa de M. Bakhtin ${ }^{17}$. E suas personagens, como Fiédia Protássov, realizam antes aquilo com o que sonha o autor.

Essa peça de Tolstói é muito pessoal. Trata-se de questão, talvez, mais dolorida no último período da vida: um desejo profundo e permanente de fugir para fora da família, para fora do casamento... Em junho de 1884, Tolstói anota no seu diário: “Tudo ficou terrivelmente penoso para mim. Eu fui-me embora e quis ir-me embora de vez, mas a gravidez dela [da esposa] me obrigou a voltar do meio do caminho para Tula"18.

A possibilidade de fuga é uma forte tentação durante todo o último período da vida do escritor, realizada somente no seu final quando, em 28 de outubro, Tolstói foge efetivamente de casa e faz seu último caminho terrestre até a pequena estação de trem Astápovo, onde morre em 20 de novembro de 1910

Vale a pena anotar que a principal personagem da obra inteira de Tolstói é um homem que busca a verdade, sendo esse o objetivo da sua existência terrena. Todos os prediletos heróis tolstoianos passam pela crise espiritual, pela aspiração por uma nova vida, pura e consciente. E aos personagens das obras tardias de Tolstói dá-se a oportunidade de romper radicalmente com tudo o que há de "material" e ingressar no mundo da liberdade. Esse ingresso está ligado a uma enorme força de vontade, com a negação dos condicionamentos sociais e, em geral, de tudo o que é imposto ao indivíduo pelas formas externas da sua existência. E o último drama de Tolstói, com certeza, baseia-se também nessa idéia de "afastamento" do mundo material, na idéia da liberdade espiritual em forma de renúncia de tudo que é morto e imóvel, na idéia de autodeterminação da personalidade, em oposição ao que foi dado e imposto. Por outro lado, para Tolstói isso significa uma volta à natureza humana, profundamente moral na sua origem.

O desencadear catastrófico de acontecimentos eleva o conflito dramático à colisão trágica. A impossibilidade de resolver o nó das relações familiares leva Fiédia ao suicídio de fato durante o processo de julgamento, no tribunal. Finalmente o "cadáver vivo" morre. Mas essa última cena do tribunal e do suicídio de Fiédia nem um pouco parece o final comme il faut, não resolve nada, o verdadeiro tribunal é a consciência, aquela questão que se torna central da literatura russa, desde Dostoiévski... Como aponta Lotman,

“[...] em antítese de misericórdia e justiça, a idéia russa, baseada no princípio binário, opõe-se às regras latinas, baseadas no espírito de lei: Fiat justitia - per eat mundus e Dura lex, sed lex. [...] Nisso se revela a antítese do direito estatal e de moral, de política e de santidade individuais. [...] Tolstói declara a supremacia da consciência sobre a lei e a supremacia da confissão sobre o tribunal" 19 .

Ao contrário de todas as outras obras de Tolstói, o final da peça fica aberto, tal como acontece no novo drama. 